\section{Abrasive Weeding as a Vehicle for Precision Fertilizer Management in Organic Vegetable Production}

\author{
Tran Kim Ngan Luong ${ }^{1}$, Frank Forcella ${ }^{2}$, Sharon A. Clay ${ }^{3}$, \\ Michael S. Douglass ${ }^{4}$, and Sam E. Wortman ${ }^{1}$
}

AdDitional INDEX wORDs. Brassica olevacea, broccoli, Capsicum annuum, nitrogen management, organic farming, pepper, weed management

Summary. Abrasive weeding is a nonchemical weed control tactic that uses small, gritty materials propelled with compressed air to destroy weed seedlings. Organic fertilizers have been used successfully as abrasive grits to control weeds, but the goal for this study was to explore the effects of fertilizer grit, application rates, and background soil fertility on weeds, plant available nitrogen (N) uptake, and crop yield. Field trials were conducted in organic 'Carmen' sweet red pepper (Capsicum annumm) and organic 'Gypsy' broccoli (Brassica olevacea var. italica) and treatments included organic fertilizer grit $(8 \mathrm{~N}-0.9 \mathrm{P}-3.3 \mathrm{~K}$ vs. $3 \mathrm{~N}-3.1 \mathrm{P}-3.3 \mathrm{~K})$, grit application rates (low vs. high), compost amendments (with and without), and weedy and weed-free controls. Weed biomass was harvested at 84 days and 65 days after transplanting for pepper and broccoli, respectively. Simulated total plant available $\mathbf{N}$ (nitrate + ammonium) uptake was measured with ion exchange resin stakes between 7 and 49 days after the first of two grit applications. Produce was harvested at maturity, graded for marketability, and weighed. The higher grit application rate, regardless of fertilizer type, reduced the weed biomass by $75 \%$ to $89 \%$ for pepper and by $86 \%$ to $99 \%$ for broccoli. By 5 weeks after the first grit application, simulated plant $\mathrm{N}$ uptake was greatest following grit application with the $8 \% \mathrm{~N}$ fertilizer, followed by the $3 \% \mathrm{~N}$ fertilizer, and lowest in the weedy control. The high grit application rate of $8 \% \mathrm{~N}$ fertilizer increased pepper yield by $112 \%$ compared with the weedy control, but it was similar to that of the weed-free control. Broccoli was less responsive to abrasive grits, with yield changes ranging from no difference to up to a $36 \%$ increase (relative to the weedy control) depending on the application rate and compost amendment. This is the first evidence indicating that the nutrient composition of organic fertilizer abrasive grits can influence in-season soil $\mathrm{N} \mathrm{dy}$ namics, weed competition, and crop yield. The results suggest that abrasive weeding technology could be leveraged to improve the precision of in-season fertilizer management of organic crops.

$\mathrm{O}$ rganic weed management of vegetable crops typically includes a combination of crop rotation, tillage, hand weeding, mowing, and mulching with plastic films (Baker and Mohler, 2015; Kasirajan and Ngouajio, 2012; Wang et al., 2008). However, considerable research has been performed to develop new weed control tactics for organic growers, including flame weeding (Melander et al., 2005), laser weeding (Mathiassen et al., 2006), steam and hot water or oil treatments (Kristoffersen et al., 2008; Zhang et al., 2012), electric current treatments (Sahin and Yalınkilic, 2017), abrasive weeding (Wortman, 2014), biobased herbicides (Baker and Mohler, 2015), cover crop mulching (Crawford et al., 2018), and biobased and biodegradable mulches (Kasirajan and Ngouajio, 2012). The efficacy of each method varies with soil conditions, weather, crop type, growth stage, and weed species present. As a result, successful ecological weed management on a given farm often requires a diverse and adaptive suite of tactics (Liebman et al., 1997).

Plastic mulch films provide excellent weed control for organic vegetable bed-tops, but weeds that escape and grow through the crop planting hole can reduce yields by up to $44 \%$; therefore, they must be managed (Wortman, 2015). Abrasive weeding is a physical weed management tactic that shreds newly emerged weed seedlings with grits propelled by compressed air (Forcella, 2009). It has been used to successfully manage weeds in the crop planting hole of plastic and bioplastic mulch film, with negligible damage to the crop or mulch (Braun et al., 2019). Any small, gritty material can be used for abrasive weeding, and many have been tested, including granulated corn (Zea mays) gluten meal, corn cob grit, soybean (Glycine max) meal, greensand fertilizer, and walnut (Juglans sp.) shell grit (Wortman, 2014). Abrasive weeding with organic fertilizers as abrasive grits can increase crop growth, yield, and profitability due to the increased plant available $\mathrm{N}$ following mineralization of organic $\mathrm{N}$ from the abrasive grits (Braun et al., 2019; Carlson et al., $2020)$. In-season delivery of $\mathrm{N}$ fertilizer via abrasive grits could shift the balance of crop-weed competition by improving the synchrony of soil $\mathrm{N}$ availability and peak crop demand (Liebman and Davis, 2000; Wortman et al., 2011).

Nitrogen requirements are significant for most vegetable crops, yet plant available $\mathrm{N}$ is often limiting in organic production due to poor synchrony between $\mathrm{N}$ mineralization and

\begin{tabular}{llll}
\hline $\begin{array}{l}\text { Units } \\
\text { To convert U.S. to SI, } \\
\text { multiply by }\end{array}$ & U.S. unit & SI unit & $\begin{array}{l}\text { To convert SI to U.S., } \\
\text { multiply by }\end{array}$ \\
\hline 29.5735 & $\mathrm{fl} \mathrm{oz}$ & $\mathrm{mL}$ & 0.0338 \\
7.8125 & $\mathrm{fl} \mathrm{oz} / \mathrm{gal}$ & $\mathrm{mL} \cdot \mathrm{L}^{-1}$ & 0.1280 \\
0.3048 & $\mathrm{ft}$ & $\mathrm{m}$ & 3.2808 \\
0.0929 & $\mathrm{ft}^{2}$ & $\mathrm{~m}^{2}$ & 10.7639 \\
3.7854 & $\mathrm{gal}$ & $\mathrm{L}$ & 0.2642 \\
2.54 & inch(es) & $\mathrm{cm}$ & 0.3937 \\
6.4516 & inch & $\mathrm{cm}$ & 0.1550 \\
0.4536 & $\mathrm{lb}$ & $\mathrm{kg}$ & 2.2046 \\
1.1209 & $\mathrm{lb} / \mathrm{acre}$ & $\mathrm{kg} \cdot \mathrm{ha}^{-1}$ & 0.8922 \\
4.8824 & $\mathrm{lb} / \mathrm{ft}^{2}$ & $\mathrm{~kg} \cdot \mathrm{m}^{-2}$ & 0.2048 \\
1.6093 & $\mathrm{mph}$ & $\mathrm{km} \cdot \mathrm{h}^{-1}$ & 0.6214 \\
28.3495 & $\mathrm{oz}$ & $\mathrm{g}$ & 0.0353 \\
93.0102 & $\mathrm{oz} / \mathrm{ft}$ & $\mathrm{g} \cdot \mathrm{m}^{-1}$ & 0.0108 \\
1 & $\mathrm{ppm}$ & $\mathrm{mg} \cdot \mathrm{kg}^{-1}$ & 1 \\
1 & $\mathrm{ppm}$ & $\mathrm{mg} \cdot \mathrm{L}^{-1}$ & 1 \\
6.8948 & $\mathrm{psi}$ & $\mathrm{kPa}$ & 0.1450 \\
$\left({ }^{\circ} \mathrm{F}-32\right) \div 1.8$ & ${ }^{\circ} \mathrm{F}$ & ${ }^{\circ} \mathrm{C}$ & $\left({ }^{\circ} \mathrm{C} \times 1.8\right)+32$ \\
& & & \\
\hline
\end{tabular}


crop uptake requirements (Mikkelsen and Hartz, 2008; Noll et al., 2020). Net $\mathrm{N}$ mineralization from organic fertilizers is driven by the $\mathrm{N}$ content and chemical composition (e.g., carbon-to-N ratio) of the organic fertilizer and the mineralization (or immobilization) rate of the soil (Flavel and Murphy, 2006; Kumar and Goh, 2003; Stadler et al., 2006). Therefore, it is possible to leverage the nutrient composition of organic fertilizer abrasive grits to more precisely manage soil $\mathrm{N}$ availability in organic vegetables while concurrently providing physical control of weeds in the crop planting hole of plasticulture systems.

The goal of this study was to explore the possibility of manipulating soil $\mathrm{N}$ availability and crop responses through the use of organic fertilizer abrasive grits with variable $\mathrm{N}$ contents. The specific objectives were to quantify weed biomass, potential plant available $\mathrm{N}$ uptake, and yield of organic 'Carmen' sweet red pepper (Capsicum annuum) and organic 'Gypsy' broccoli (Brassica oleracea var. italica) in response to variable abrasive grit fertilizer analyses, application rates, and background soil fertility.

\section{Materials and methods}

STUDY SITE AND EXPERIMENTAL DESIGN. Two field trials were conducted in 2017 at the University of Illinois Sustainable Student Farm in

Received for publication 10 Sept. 2020. Accepted for publication 17 Nov. 2020.

Published online 18 December 2020

${ }^{1}$ Department of Agronomy and Horticulture, University of Nebraska-Lincoln, 279 Plant Sciences Hall, Lincoln, NE 68583

${ }^{2}$ North Central Soil Conservation Research Laboratory, U.S. Department of Agriculture-Agricultural Research Service, 803 Iowa Avenue, Morris, MN 56267

${ }^{3}$ Department of Agronomy, Horticulture \& Plant Science, South Dakota State University, Box 2140C, University Station, Brookings, SD 57007

${ }^{4}$ Department of Crop Sciences, University of Illinois, Urbana, IL 61801

This research was funded in part by the U.S. Department of Agriculture, National Institute of Food and Agriculture (USDA NIFA), Organic Agriculture Research and Extension Initiative (OREI), award \#2014-51300-22233, and the Nebraska Agricultural Experiment Station with funding from the Hatch Act (accession 1014303) through the USDA NIFA.

S.E.W. is the corresponding author. E-mail: swortman@ unl.edu.

This is an open access article distributed under the CC BY-NC-ND license (https://creativecommons.org/ licenses/by-nc-nd/4.0/).

https://doi.org/10.21273/HORTTECH04714-20
Urbana, IL (lat. $40.08^{\circ} \mathrm{N}$, long. $88.22^{\circ} \mathrm{W}$, elevation $725 \mathrm{ft}$ ). The predominant soil texture at the farm is loam consisting of $31 \%$ sand, $45 \%$ silt, and $24 \%$ clay. Background soil chemical conditions (to a depth of $20 \mathrm{~cm}$ ) at the experimental site included the following: $7.6 \mathrm{pH}$ (1:1 dilution method); $7 \mathrm{mg} \cdot \mathrm{kg}^{-1}$ nitrate $\left(\mathrm{NO}_{3^{-}}\right.$ $\mathrm{N}) ; 74 \mathrm{mg} \cdot \mathrm{kg}^{-1}$ phosphorus $(\mathrm{P})$; and $203 \mathrm{mg} \cdot \mathrm{kg}^{-1}$ potassium $(\mathrm{K})$. The farm has been managed in accordance with U.S. Department of Agriculture (USDA) National Organic Program guidelines since its establishment in 2009.

The experiment was arranged using a split-split-plot randomized complete block design with four replicate blocks and three factors across two crops. Factors included compost amendment (whole plots), organic fertilizer grit (split plot), and abrasive grit application rate (split-split plot). The two organic fertilizer grits included high and low $\mathrm{N}$ comparisons of $8 \mathrm{~N}-0.9 \mathrm{P}-3.3 \mathrm{~K}$ (hereafter referred to as 58 ) and $3 \mathrm{~N}-3.1 \mathrm{P}-3.3 \mathrm{~K}$ (hereafter referred to as S3) organic fertilizer products (Suståne Natural Fertilizer, Cannon Falls, MN). Other than the N and $\mathrm{P}$ chemical compositions, these fertilizer products had identical chemical and physical properties (e.g., feedstock, manufacturing process, grit mesh size, and color). Although the $P$ content did vary between fertilizers, soils on this farm were P-sufficient (Mehlich $\mathrm{P}=74 \mathrm{mg} \cdot \mathrm{kg}^{-1}$ ) and $\mathrm{NO}_{3}$ $\mathrm{N}$-deficient $\left(\mathrm{NO}_{3}-\mathrm{N}=7 \mathrm{mg} \cdot \mathrm{kg}^{-1}\right)$; therefore, we expected that any observed differences between these treatments would be primarily the result of $\mathrm{N}$ content differences. A nontreated weedy control and a hand-weeded, weed-free control were included in each replicate block. The two grit application rate treatments included a low rate, for which a single pass was made on one side of each row at two different application intervals, and a high rate, for which a single pass was made on both sides of a row (resulting in two passes) at each of two application intervals (9-10 $\mathrm{d}$ apart). Compost amendment treatments included: 1) municipal yard waste compost ( $1.3 \%$ total N, $0.02 \%$ $\mathrm{P}, 0.1 \% \mathrm{~K})$ incorporated at $105 \mathrm{lb} /$ plot $3 \mathrm{~d}$ before laying mulch and transplanting crops; and 2) no compost control. This resulted in an application rate of $3.3 \mathrm{lb} / \mathrm{ft}^{2}$ for pepper and $3.1 \mathrm{lb} / \mathrm{ft}^{2}$ for broccoli (due to differences in plot sizes). Compost amendments were used to introduce variability in background $\mathrm{N}$ availability before abrasive grit application with organic fertilizers. We hypothesized that these may influence crop responsiveness to $\mathrm{N}$ mineralized from organic fertilizer grits.

This experimental design resulted in 48 experimental units for each crop (2 grit types $\times 2$ application rates $\times 2$ compost treatments $\times 4$ replicates +2 controls in each replicate block). Each whole-plot experimental unit for pepper was $31.3 \mathrm{ft}^{2}$ $(12.5 \mathrm{ft}$ long $\times 2.5 \mathrm{ft}$ wide) and included nine pepper plants spaced $1.5 \mathrm{ft}$ apart. Each whole-plot experimental unit for broccoli was $33.6 \mathrm{ft}^{2}$ $(13.5 \mathrm{ft}$ long $\times 2.5 \mathrm{ft}$ wide $)$ and included 15 broccoli plants spaced $1.5 \mathrm{ft}$ apart in twin rows. Individual plots within rows were spaced $3 \mathrm{ft}$ apart.

Site AND CROP MANAGEMENT. Compost-amended plots had compost broadcast-spread and tilled to a depth of 4 inches. For both crops, raised bed-tops were $2.5 \mathrm{ft}$ wide, and there was $3.5 \mathrm{ft}$ between rows (measured from the edge of each bed top). A drip tape irrigation line with 6-inch emitter spacing was laid down the center of each raised bed, and beds were covered with black plastic mulch film for pepper and white-on-black plastic mulch film for broccoli. Crops were drip-irrigated regularly to maintain a minimum of $15 \%$ volumetric soil moisture for peppers and broccoli within the top 4 inches of the bed-top monitored with a soil moisture meter (FieldScout TDR Meter; Spectrum Technologies, Aurora, IL). Weeds between raised-beds were controlled with mowing and hand-weeding, whereas weeds within the crop planting holes, typically a 7.5 - to 15 -inch ${ }^{2}$ area, were the target of abrasive weeding treatments.

'Carmen' pepper plants (Johnny's Selected Seeds, Fairfield, ME) were transplanted on 18 May 2017 (7 weeks after greenhouse sowing) and fertigated immediately with $\mathrm{l} \mathrm{fl} \mathrm{oz/gal} 2 \mathrm{~N}-1.7 \mathrm{P}-$ $0.8 \mathrm{~K}$ fish emulsion (Neptune's Harvest Fish Fertilizer; Neptune's Harvest, Gloucester, MA) and $1 \mathrm{fl} \mathrm{oz} / \mathrm{gal} 0 \mathrm{~N}-$ 0P-0.8K seaweed extract (Neptune's Harvest Seaweed Plant Food), resulting in a total of $30 \mathrm{gal}$ of mixed solution for all peppers. As a result, each pepper plant 
received $\approx 0.04 \mathrm{~g} \mathrm{~N}$ via $8.8 \mathrm{fl} \mathrm{oz}$ of solution (156 ppm $\mathrm{N}$ ) at the time of transplanting. Pepper plants received no additional fertilizer throughout the experiment, except in the form of abrasive grit or compost experimental treatments. Consistent with previous research (Braun et al., 2019; ErazoBarradas et al., 2019; Forcella, 2012; Wortman, 2015), abrasive grits were applied twice during the growing season when emerged weeds were between the cotyledon and two-leaf growth stage. Grit applications for pepper occurred 15 and $24 \mathrm{~d}$ after transplanting (DAT).

'Gypsy' broccoli plants (Johnny's Selected Seeds) were transplanted on 17 July 2017 (6 weeks after greenhouse sowing) and fertigated immediately with $1 \mathrm{fl} \mathrm{oz} / \mathrm{gal} 2 \mathrm{~N}-1.7 \mathrm{P}-0.8 \mathrm{~K}$ fish emulsion and $1 \mathrm{fl} \mathrm{oz} / \mathrm{gal} 0 \mathrm{~N}-0 \mathrm{P}-$ $0.8 \mathrm{~K}$ seaweed extract, resulting in $50 \mathrm{gal}$ of total solution for all broccoli. As a result, each broccoli plant received $\approx 0.04 \mathrm{~g} \mathrm{~N}$ via $8.8 \mathrm{fl} \mathrm{oz}$ of solution (156 ppm $\mathrm{N}$ ) at the time of transplanting. Broccoli plants received no additional fertilizer throughout the experiment, except in the form of abrasive grit or compost experimental treatments. The two grit application intervals for broccoli were 12 and 22 DAT.

In both experiments, the prototype abrasive grit applicator used by Braun et al. (2019) was used for abrasive grits applications (Fig. 1). The grits were propelled by compressed air (135 psi) from a single hand-held nozzle of the applicator. The flow of grits could not be paused or pulsed during application; therefore, abrasive grits were applied continuously in a strip within crop rows for all experimental plots (despite the presence of mulch film between crop planting holes). The resulting average application rate for one field pass in this study was $35 \mathrm{~g} \cdot \mathrm{m}^{-1}$ per row of planted crops, and the $\mathrm{N}$ fertilizer rate depended on the experimental treatment (Table 1).

Data collection. The weed biomass of pepper was measured at 84 DAT in five out of nine crop planting holes. Aboveground weed biomass was clipped at the soil surface, dried at $60^{\circ} \mathrm{C}$ to constant mass, and weighed. The weed biomass of broccoli was measured 65 DAT in 5 out of 15 planting holes. The timing of weed biomass harvest was intended to maximize the effects of crop-weed competition among treatments while also preventing weeds from producing viable seed.

Ion exchange resin stakes (PRS Probes; Western Ag Innovations, Saskatoon, SK, Canada) were used to measure potential plant available soil $\mathrm{N}$ and crop uptake in the nonfertilized and high abrasive grit rate treatments for pepper. Estimates of plant available soil $\mathrm{N}$ using ion exchange resin stakes are often positively correlated with soil $\mathrm{N}$ point measurements, plant $\mathrm{N}$ uptake, and crop yield (Nyiraneza et al., 2009). One week after the first grit application, anion $\left(\mathrm{NO}_{3}{ }^{-}\right.$ $\mathrm{N})$ and cation [ammonium $\left(\mathrm{NH}_{4}\right.$ $\mathrm{N})$ ] resin stakes were buried in pairs to a depth of $14 \mathrm{~cm}$ in four alternating planting holes within each plot. Stakes remained in the soil for 2 weeks; then, they were removed and replaced two more times by new pairs in the exact same location (resulting in a 6-week total incubation period between 7 and $49 \mathrm{~d}$ after the first grit application). When removed, probes were washed using reverse osmosis water and sent to Western Ag Innovations for analysis of $\mathrm{NO}_{3}-\mathrm{N}$ and $\mathrm{NH}_{4}-\mathrm{N}$.

Pepper fruit was harvested at maturity across 10 possible days beginning 9 Aug. and ending 26 Oct. Broccoli heads were harvested at maturity across 10 possible days beginning 25 Sept. and 30 Oct., and some plants produced more than one marketable head. Produce was graded as marketable or cull, counted, and weighed fresh. Cull produce included those that had significant physical deformities, rot, or disease infestation, and all other produce were graded as marketable (but not graded according to USDA standards). Yield was pooled across individual harvest dates to analyze the cumulative growing season yield for each crop.

Statistical analysis. Data for the pepper and broccoli experiments were analyzed separately with an analysis of variance (ANOVA) using the GLIMMIX procedure in SAS (version 9.4; SAS Institute, Cary, NC) to assess differences in weed biomass, plant available soil $\mathrm{N}$, and yield among treatments. Fixed effects in the models for weed biomass and yield included abrasive fertilizer grit, grit application rate, compost amendment, and all possible two-way and three-way interactions. The model for

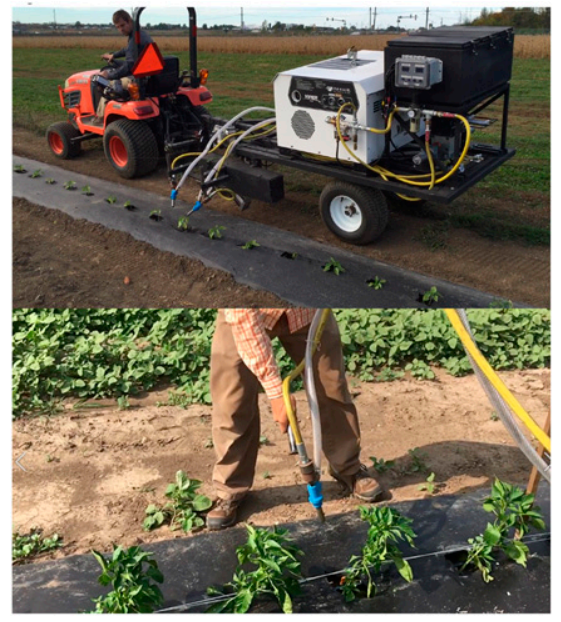

Fig. 1. Prototype abrasive grit applicator (top image) with air compressor (white), fertilizer grit hopper (black), compressed air and grit delivery tubes (yellow and white, respectively), and prototype grit delivery nozzles (blue and metallic); and a hand-held application of organic fertilizer grit in pepper planting holes in this study (bottom image).

plant available $\mathrm{N}$ included additional fixed effects for the incubation date and the interactions among the incubation date, abrasive fertilizer grit, and compost amendment (but excluded the application rate). The random effect in all models was replicate block. Data residuals were checked for assumptions of the ANOVA using the UNIVARIATE procedure in SAS (normal distribution and homogeneity of variance). Weed biomass residuals of pepper and broccoli experiments were not normally distributed; therefore, a Poisson distribution with an $l n$-link function was used to fit the distribution. Treatment means were compared using the Tukey-Kramer multiple comparisons test, and orthogonal contrasts were used to compare pooled treatment means in the absence of significant interactions (at a significance level of $\alpha=0.05$ ).

\section{Results and discussion}

WeEd bIOMAss. Weed community biomass of pepper was composed of $\approx 51 \%$ grass weeds [primarily green foxtail (Setaria viridis)] and 49\% broadleaf weeds [a mix of pigweed (Amaranthus sp.) and common lambsquarters (Chenopodium album)]. Total weed biomass sampled from peppers was 
influenced by the three-way interaction of fertilizer grit, grit application rate, and compost amendment $(P<0.0001)$. Abrasive weeding with the high rate of S3 resulted in less weed biomass compared with the high rate of $S 8$ (with or without compost amendment) (Fig. 2). Any weeds not controlled by the abrasive grit treatment would have competed for plant available $\mathrm{N}$ mineralized from the grits, which explained the increased biomass following the high rate of grit applications with S8 for pepper. Consistent with this result, Carlson et al. (2020) found that velvetleaf (Abutilon theophrasti) biomass increased in response to the S8 fertilizer delivered at rates typical for abrasive weeding.

For each fertilizer grit type, the higher application rate reduced the weed biomass of pepper. The weed biomass of pepper trended lower in treatments with no compost compared with compost-amended treatments (Fig. 2). An orthogonal contrast between the weedy control and both abrasive fertilizer grits at the high application rate showed that weed biomass was reduced by $89 \%$ in plots with no compost $(P<0.0001)$ and by $75 \%$ in plots with compost $(P<$ $0.0001)$. This result is also consistent with that of Carlson et al. (2020) because any weed escaping after the abrasive grit applications would benefit from increased soil fertility realized in compost-amended plots. Moreover, overfertilization in organic systems has been shown to benefit weeds more than crops (Little et al., 2015); the combination of compost and high abrasive grit application rates in this study may have resulted in an overabundance of plant available nutrients.

The weed community biomass of broccoli was composed of $\approx 77 \%$ grass weeds (primarily green foxtail) and $23 \%$ broadleaf weeds (a mix of pigweed and common lambsquarters). The total weed biomass sampled for broccoli was influenced by the twoway interactions of fertilizer grit and grit application rate $(P<0.0001)$, grit application rate and compost amendment $(P<0.0001)$, and fertilizer grit and compost amendment $(P<$ $0.001)$. Consistent with results the for pepper, the high rate of S3 resulted in less weed biomass compared with the high rate of S8 (with or without compost amendment) (Fig. 3 ). Orthogonal contrasts suggest that

Table 1. Average grit application rates for each fertilizer grit for pepper and broccoli. Application rate estimates are the sum of field passes (two or four) across both application dates. Linear row and area estimates assume a mean tractor speed of $1 \mathrm{mph}\left(1.6 \mathrm{~km} \cdot \mathrm{h}^{-1}\right)$ and crop between-row spacing of $6 \mathrm{ft}$ $(1.83 \mathrm{~m})$.

\begin{tabular}{lccc}
\hline & \multicolumn{3}{c}{ Mean application rate } \\
\cline { 2 - 4 } Fertilizer grit and rate & $\left(\mathbf{g} \cdot \mathbf{m}^{-1} \text { per row }\right)^{\mathrm{z}}$ & $(\mathbf{l b} / \text { acre })^{\mathrm{z}}$ & $(\mathbf{l b} /$ acre nitrogen $)$ \\
\hline 8N-0.9P-3.3K organic fertilizer & & & \\
Low rate $=$ two passes & 70 & 340 & 27 \\
High rate $=$ four passes & 140 & 680 & 54 \\
$3 \mathrm{~N}-3.1 \mathrm{P}-3.3 \mathrm{~K}$ organic fertilizer & & & \\
Low rate $=$ two passes & 70 & 340 & 10 \\
High rate $=$ four passes & 140 & 680 & 20 \\
\hline
\end{tabular}

${ }^{\mathrm{z}} 1 \mathrm{~g} \cdot \mathrm{m}^{-1}$ row $=0.0108 \mathrm{oz} / \mathrm{ft}$ row, $1 \mathrm{lb} /$ acre $=1.1209 \mathrm{~kg} \cdot \mathrm{ha}^{-1}$.

${ }^{\mathrm{y}}$ Suståne Natural Fertilizer, Cannon Falls, MN.

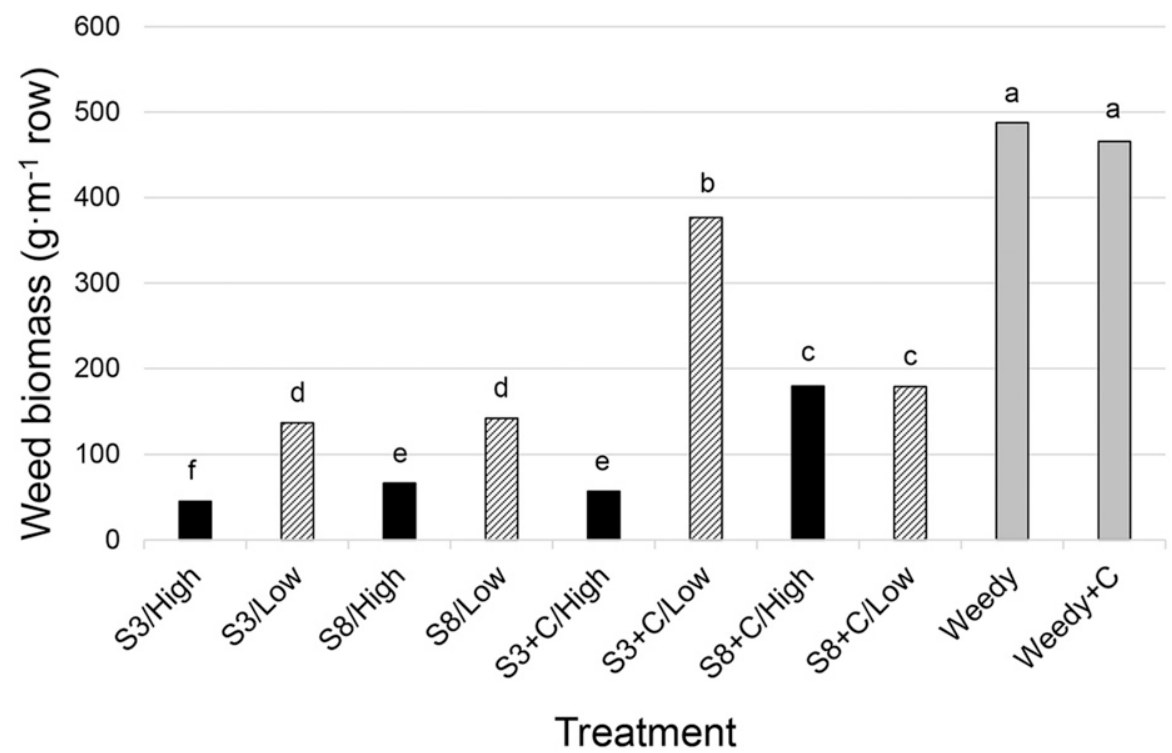

Fig. 2. Effects of abrasive fertilizer grit [3N-3.1P-3.3K organic fertilizer grit (S3) and $8 \mathrm{~N}-0.9 \mathrm{P}-3.3 \mathrm{~K}$ organic fertilizer grit (S8)], grit application rate [four field passes of abrasive grit applicator for a total rate of $140 \mathrm{~g} \cdot \mathrm{m}^{-1}$ row (high) and two field passes of abrasive grit applicator for a total rate of $70 \mathrm{~g} \cdot \mathrm{m}^{-1}$ row (low)], and compost amendment $\left[3.3 \mathrm{lb} / \mathrm{ft}^{2}\left(16.11 \mathrm{~kg} \cdot \mathrm{m}^{-2}\right)\right.$ compost applied before planting $(+C)$ ] on weed biomass during the pepper trial (weedy = weedy control). The SE values are not included because data were back-transformed; however, different letters above the bars indicate significant differences as determined by the TukeyKramer multiple comparisons tests at a significance level of $\alpha=0.05 ; 1 \mathrm{~g} \cdot \mathrm{m}^{-1}=$ $0.0108 \mathrm{oz} / \mathrm{ft}$.

fertilizer grits applied at the higher rate (regardless of fertilizer analysis) reduced weed biomass by $86 \%$ in plots without compost $(P<0.0001)$ and by $99 \%$ in plots with compost $(P<$ 0.0001 ). For each fertilizer grit, the higher application rate reduced weed biomass. The weed biomass was lowest when combining the higher grit application rate with the compost amendment. The opposite effect of compost was observed for pepper, for which compost increased the weed biomass. The differences might be explained by the varying intensity of weed competition between crops. The weedy controls for broccoli averaged $206 \mathrm{~g} \cdot \mathrm{m}^{-1}$ per row compared with $488 \mathrm{~g} \cdot \mathrm{m}^{-1}$ per row for pepper. Reduced weed competition would reduce competition for plant-available $\mathrm{N}$, even if it was in overabundance. Perhaps more important are differences in the canopy architecture of the two crops. The large leaves and relatively compact growth habit of broccoli improve its competition for light resources (Brainard et al., 


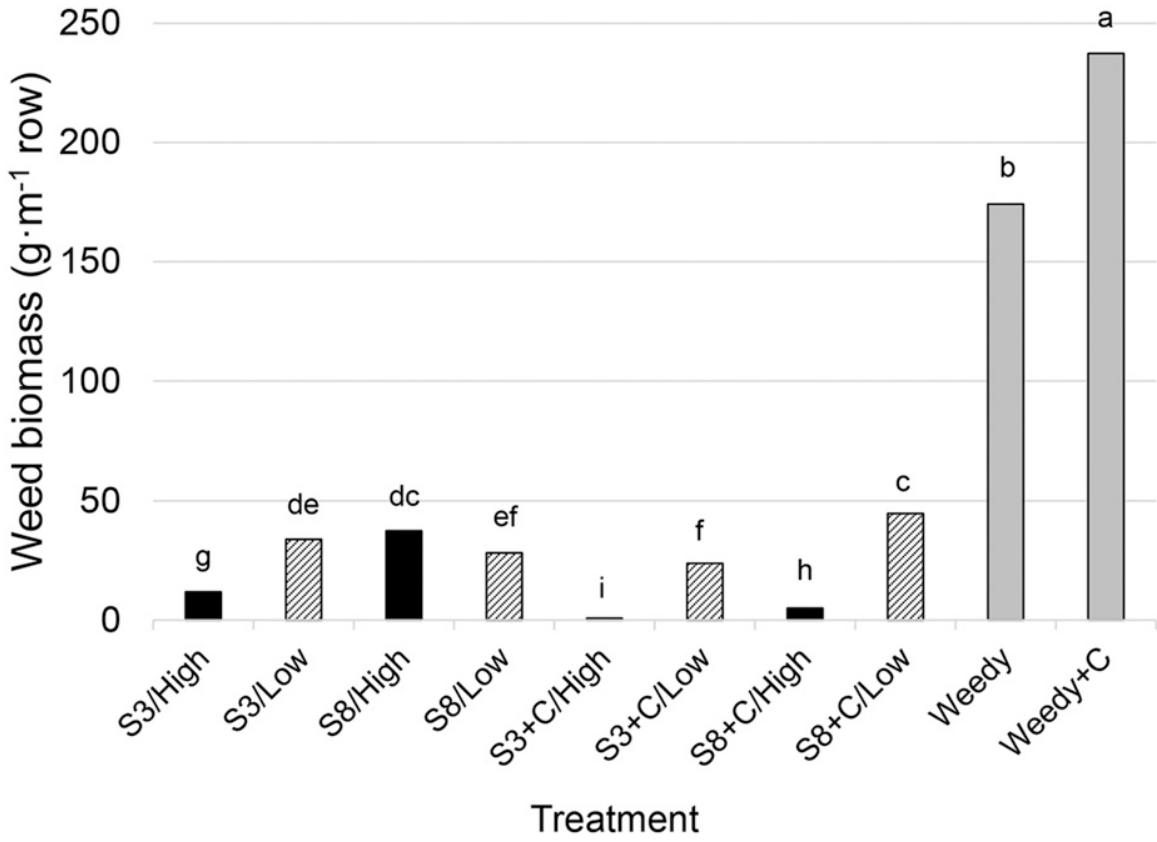

Fig. 3. Effects of abrasive fertilizer grit [3N-3.1P-3.3K organic fertilizer grit (S3) and $8 \mathrm{~N}-0.9 \mathrm{P}-3.3 \mathrm{~K}$ organic fertilizer grit (S8)], grit application rate [four field passes of abrasive grit applicator for a total rate of $140 \mathrm{~g} \cdot \mathrm{m}^{-1}$ row (high) and two field passes of abrasive grit applicator for a total rate of $70 \mathrm{~g} \cdot \mathrm{m}^{-1}$ row (low)], and compost amendment $\left[3.3 \mathrm{lb} / \mathrm{ft}^{2}\left(16.11 \mathrm{~kg} \cdot \mathrm{m}^{-2}\right)\right.$ compost applied before planting $\left.(+\mathrm{C})\right]$ on weed biomass during the broccoli trial (weedy = weedy control). The SE values are not included because data were back-transformed; however, different letters above the bars indicate significant differences as determined by the Tukey-Kramer multiple comparisons tests at a significance level of $\alpha=0.05 ; 1 \mathrm{~g} \cdot \mathrm{m}^{-1}=0.0108 \mathrm{oz} / \mathrm{ft}$.

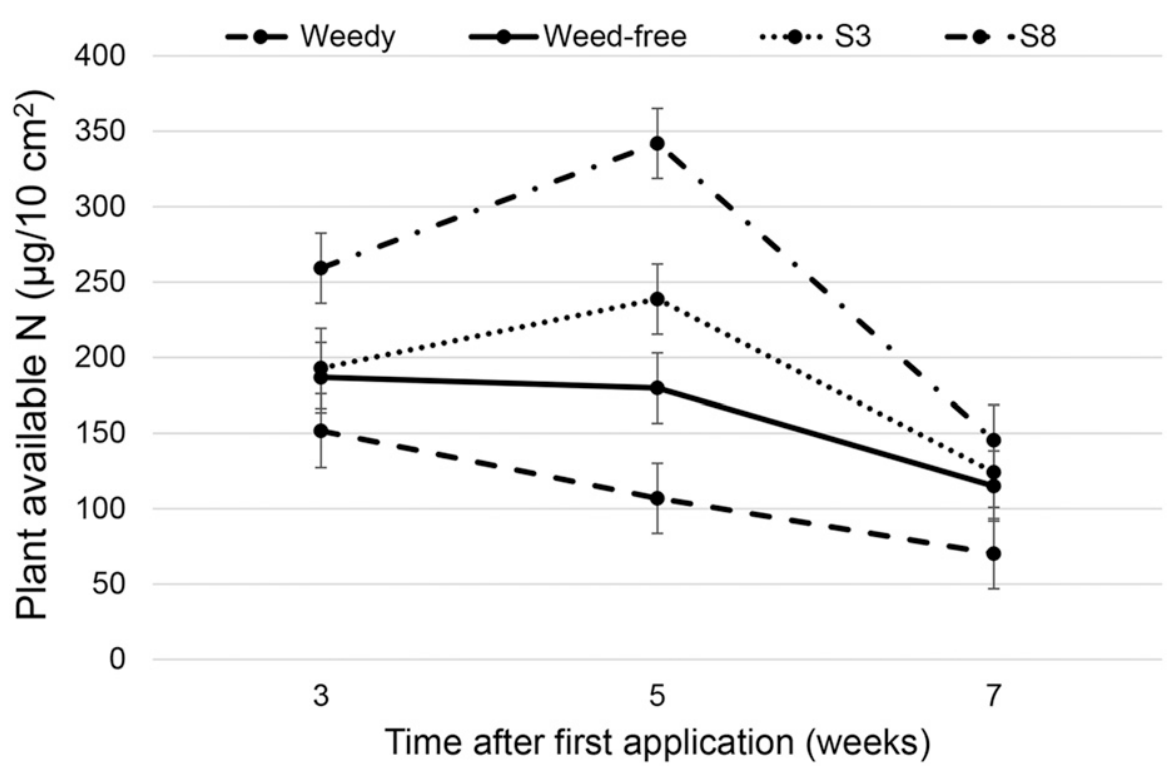

Fig. 4. Effects of abrasive fertilizer grit [3N-3.1P-3.3K organic fertilizer grit (S3) and 8N-0.9P-3.3K organic fertilizer grit (S8)] on simulated total plant available nitrogen (N) uptake across three 2 -week soil incubation periods between 7 and $49 \mathrm{~d}$ after the first abrasive grit application [compared with the weedy control (weedy) and weedfree control (weed-free) ]. Error bars represent $\pm 1 \mathrm{sE} ; 1 \mu \mathrm{g} / 10 \mathrm{~cm}^{2}=0.1417 \mathrm{oz} /$ acre .

2005), especially in plasticulture systems in which weeds only emerge beneath the canopy of the plant (in the crop planting hole). the higher grit application rate (two passes on both sides of the row compared with one) was consistently the most important factor for maximizing weed suppression (Figs. 2 and 3). These results are consistent with those of Forcella (2012), who reported a $90 \%$ weed reduction in maize after two grit applications; however, they are an improvement over the results reported by Wortman (2015) and Braun et al. (2019). Wortman (2015) reported that two applications of abrasive grits reduced weed biomass by $63 \%$ for tomato (Solanum lycopersicum) and $80 \%$ for pepper. Braun et al. (2019) reduced the weed biomass of pepper by $81 \%$ to $84 \%$ with two abrasive grit applications. Improved weed efficacy in this study can likely be attributed to greater application rates; making a pass on both sides of the crop row (the treatment with the high application rate) at two different times nearly doubled the application rate used by Braun et al. (2019).

Simulated plant aVailable N UPTAKE. Simulated total plant available $\mathrm{N}$ uptake (hereafter referred to as $\mathrm{N}$ uptake; micrograms of $\mathrm{N}$ per 10 $\mathrm{cm}^{2}$ per 2 weeks) during the pepper experiment was influenced by the interactions of the fertilizer grit and incubation date $(P<0.001)$. Throughout all incubation periods, $\mathrm{N}$ uptake was greatest following the application of S8, followed by S3, the weed-free control, and the weedy control (differences were most pronounced 5 weeks after the first grit application) (Fig. 4). In the weedy control plots, $\mathrm{N}$ uptake steadily decreased throughout the incubation period, indicating increased $\mathrm{N}$ competition from weeds in the absence of grit applications. With reduced weed competition and additional plant available $\mathrm{N}$ supplied by organic fertilizer grits, $\mathrm{N}$ uptake was two- to three-times greater in grit-treated plots by 5 weeks after grit application compared with the weedy control.

Braun et al. (2019) did not observe significant increased $\mathrm{N}$ uptake (measured via ion exchange resin stakes) following similar application rates of soybean meal abrasive grits (7\% $\mathrm{N}$ by weight) or the same $\mathrm{S} 8$ fertilizer ( $8 \% \mathrm{~N}$ by weight) compared with weedy and weed-free checks. Moreover, Braun et al. (2019) observed no difference in $\mathrm{N}$ uptake 


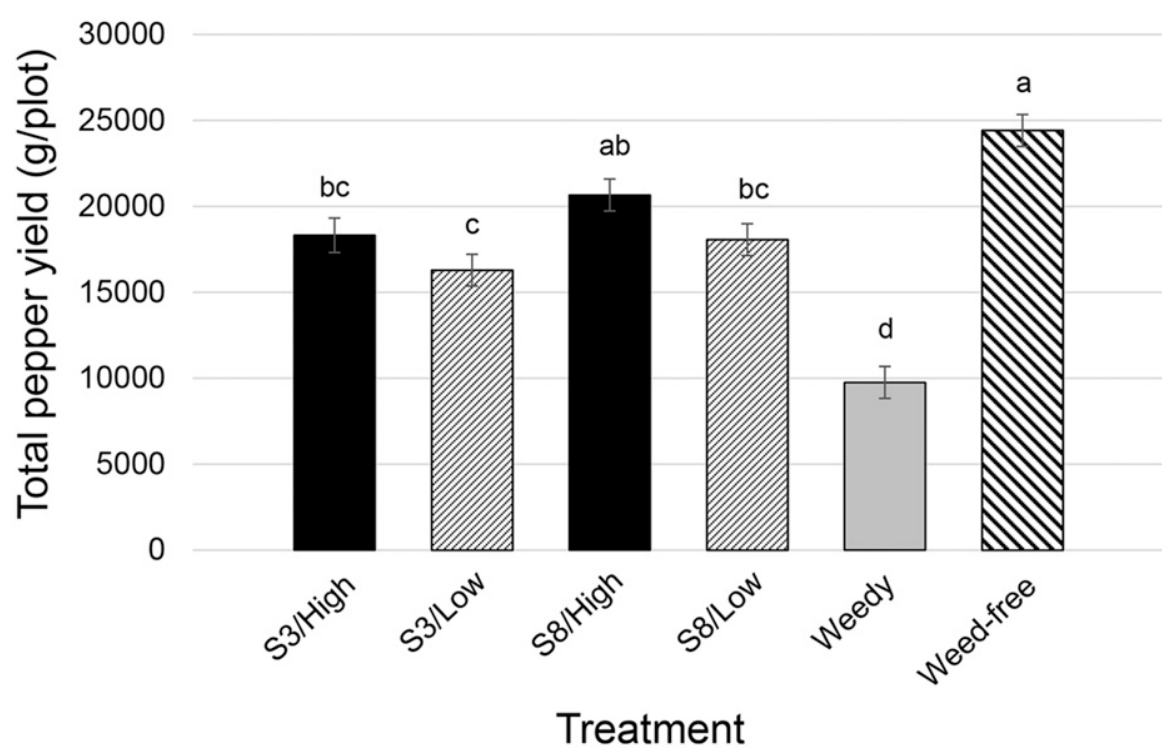

Fig. 5. Effects of abrasive fertilizer grit [3N-3.1P-3.3K organic fertilizer grit (S3) and $8 \mathrm{~N}-0.9 \mathrm{P}-3.3 \mathrm{~K}$ organic fertilizer grit (S8)] and grit application rate [four field passes of abrasive grit applicator for a total rate of $140 \mathrm{~g} \cdot \mathrm{m}^{-1}$ row (high) and two field passes of abrasive grit applicator for a total rate of $70 \mathrm{~g} \cdot \mathrm{m}^{-1}$ row (low)] on the total fresh pepper fruit yield compared with the weedy and weed-free controls. Each plot was $31.3 \mathrm{ft}^{2}$ $\left(2.91 \mathrm{~m}^{2}\right)$. Error bars represent $\pm 1 \mathrm{SE}$, and different letters above the bars indicate significant differences as determined by the Tukey-Kramer multiple comparisons tests at a significance level of $\alpha=0.05 ; 1 \mathrm{~g} \cdot \mathrm{m}^{-1}=0.0108 \mathrm{oz} / \mathrm{ft}, 1 \mathrm{~g}=0.0353 \mathrm{oz}$.

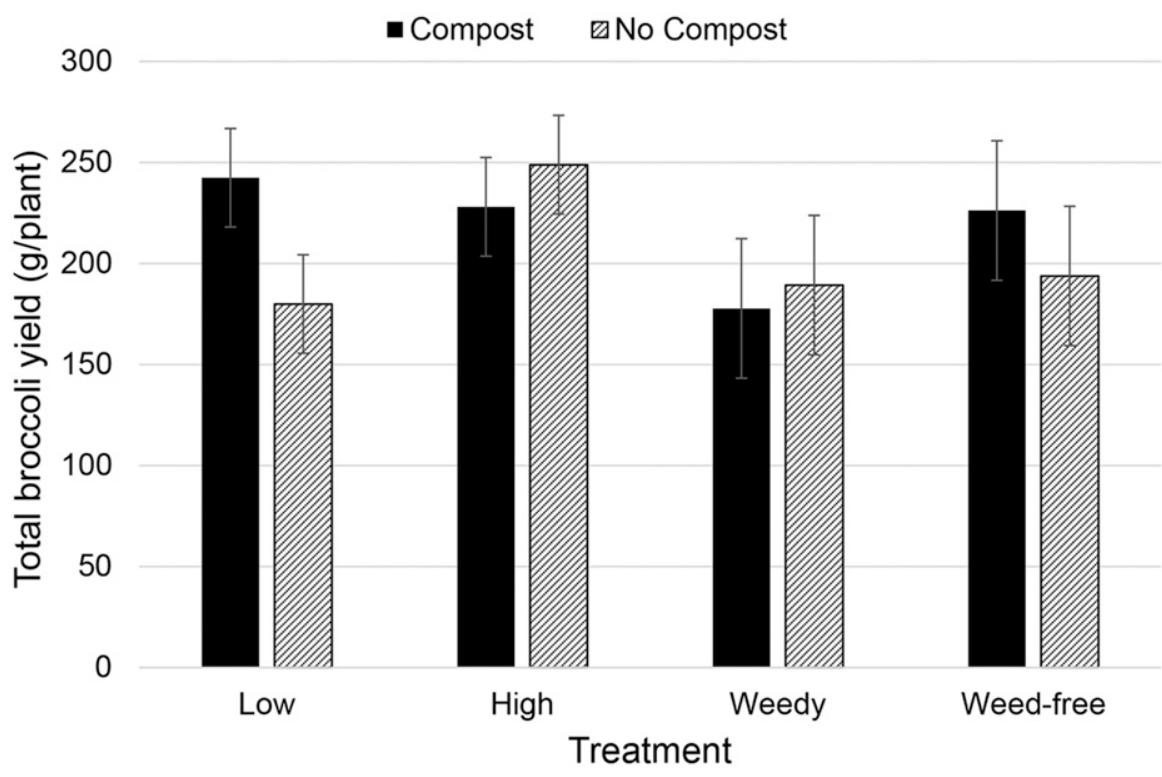

Fig. 6. Effects of abrasive grit application rates [four field passes of abrasive grit applicator for a total rate of $140 \mathrm{~g} \cdot \mathrm{m}^{-1}$ row (high) and two field passes of abrasive grit applicator for a total rate of $70 \mathrm{~g} \cdot \mathrm{m}^{-1}$ row (low)] and compost amendment [compost applied preplanting at a rate of $3.1 \mathrm{lb} / \mathrm{ft}^{2}\left(15.14 \mathrm{~kg} \cdot \mathrm{m}^{-2}\right)$ (compost) and no compost applied preplanting (no compost)] on the total broccoli yield (g/plant) compared with the weedy and weed-free controls. Each plot was $33.6 \mathrm{ft}^{2}\left(3.12 \mathrm{~m}^{2}\right)$. Error bars represent $\pm 1 \mathrm{SE}$, and different letters above the bars indicate significant differences as determined by orthogonal contrasts at a significance level of $\alpha=0.05 ; 1 \mathrm{~g}=0.0353 \mathrm{oz}$.

between abrasive grit types; however, this was not surprising given the minor $1 \% \mathrm{~N}$ difference in their guaranteed analysis. Contrasting results abrasive grits in the crop planting hole of plastic or bioplastic mulch film, Braun et al. (2019) reported reductions of weed biomass up to $83 \%$. In contrast, high rates of fertilizer grit (either fertilizer analysis) in this study reduced weed biomass by up to $89 \%$. The reduced intensity of crop-weed competition for plant available $\mathrm{N}$ could have magnified the differences between fertilizer grits observed here. Taken together, these two studies suggest that the capacity for abrasive weeding to effectively deliver in-season crop nutrition is contingent on the weed efficacy of the technology. This is consistent with the findings of Carlson et al. (2020), who reported that organic fertilizer abrasive grits indiscriminately increased the growth of crops and weeds. Because weeds were more effectively controlled during this study than during the study by Braun et al. (2019), this is the first study to demonstrate under field conditions that abrasive weeding technology can be used as a vehicle for delivering variable and potentially more precise doses of plant available $\mathrm{N}$ to crops during the growing season.

Crop Yield. Th total pepper yield was influenced by the interaction of fertilizer grit and application rate $(P<0.0001)$. The total yield was greatest in weed-free control plots, followed by grit-treated plots (Fig. 5 ). Abrasive weeding with the high rate of S8 increased the yield by $112 \%$ compared with the weedy control. Yield gains in other grit-treated plots ranged from $67 \%$ to $88 \%$, relative to the weedy control. For each fertilizer grit, increasing the application rate tended to increase the yield, but not significantly $(P>0.05)$ (Fig. 5). Observed yield gains compared with the weedy control are greater than previous reports in pepper of $21 \%$ to $47 \%$ (Braun et al., 2019) and 30\% (Wortman, 2015). Combined with the results of the ion exchange resin stake analysis, pepper yield trends suggest that the fertilizer grit and application rate can influence soil chemical and crop growth outcomes. The significant yield difference between the high application rate of $S 8$ and the low rate of S3 lends support to the hypothesis that crop yield can be increased by using increased rates of high-N fertilizer as abrasive grits (at least when plant available $\mathrm{N}$ is a limiting factor). 
The total broccoli yield was influenced by the interaction of the grit application rate and compost amendment $(P=0.03)$. The low rate of abrasive grits (regardless of fertilizer analysis) increased broccoli yields by $36 \%$ compared with the weedy control in compost-amended plots (Fig. 6). However, in the absence of compost, only the high application rate increased the broccoli yield $(31 \%)$ relative to the weedy control. Overall, broccoli was less responsive to abrasive weeding and organic fertilizer grits than pepper. This may be due, in part, to the reduced weed biomass for broccoli relative to pepper given the differences in the growing season, crop morphology, and crop-weed competition for light (Brainard et al., 2005). Nonetheless, the results are consistent with those of Carlson et al. (2020), who demonstrated organic fertilizers as abrasive grits can increase the crop growth rate and biomass if weed competition is reduced. However, the magnitude of this benefit may be crop-specific and influenced by background soil fertility (e.g., compost amendment).

\section{Conclusions}

The weed efficacy of organic fertilizers used as abrasive grits has been previously demonstrated (Braun et al., 2019; Carlson et al., 2018; Forcella et al., 2011; Wortman 2014,2015 ), but this is the first study to report changes in soil fertility and crop-weed competition driven by differences in organic fertilizer grit nutrient analyses and application rates. This is an important finding because it suggests that abrasive weeding technology could be used as a vehicle for improving the precision of in-season fertilizer management in organic cropping systems. The fertility benefits of abrasive grits are most pronounced when the weed efficacy of grit applications is maximized. Under conditions of intense weed competition or insufficient weed control with abrasive grits (e.g., grits applied when weeds are too large or at too low of a rate), weeds that remain will compete for the increased plant available $\mathrm{N}$ mineralized from abrasive grits and limit the yield benefits to the crop. Therefore, future research should continue to focus on improving the weed efficacy of abrasive grit applications. More specifically, research is needed to optimize the velocity of fertilizer grits (with irregular shapes and absorptive properties) while minimizing potential damage to the crop and ensuring that grits stay near the crop row for soil mineralization and crop uptake (e.g., shielded or hooded applications).

\section{Literature cited}

Baker, B.P. and C.L. Mohler. 2015. Weed management by upstate New York organic farmers: Strategies, techniques and research priorities. Renew. Agr. Food Syst. 30:418-427, doi: 10.1017/ S1742170514000192.

Brainard, D.C., R.R. Bellinder, and A. DiTommaso. 2005. Effects of canopy shade on the morphology, phenology, and seed characteristics of powell amaranth (Amaranthus powellii). Weed Sci. 53:175-186, doi: 10.1614/WS-04-067Rl.

Braun, E.E., S.T. Lovell, M. Babadoost, F. Forcella, S. Clay, D. Humburg, and S.E. Wortman. 2019. Abrasive grit application in organic red pepper: An opportunity for integrating nitrogen and weed management. HortScience 54:1509-1516, doi: 10.21273/ HORTSCI14162-19.

Carlson, M., F. Forcella, S.E. Wortman, and S.A. Clay. 2018. Using abrasive grit for weed management in field crops. In: M.A. El-Esawi (ed.). Physical methods for stimulation of plant and mushroom development. IntechOpen, London, UK. doi: 10.5772/intechopen.76875.

Carlson, M., F. Forcella, S.E. Wortman, D. Clay, and S.A. Clay. 2020. Organic fertilizer abrasive grits increase soil available nitrogen, plant height and biomass. Agrosyst. Geosci. Environ. 3:e20091, doi: 10.1002/agg2.20091

Crawford, L.E., M.M. Williams, and S.E. Wortman. 2018. An early-killed rye (Secale cereale) cover crop has potential for weed management in edamame (Glycine max). Weed Sci. 66:502-507, doi: $10.1017 /$ wsc. 2018.5 .

Erazo-Barradas, M., C.N. Friedrichsen, F. Forcella, D. Humburg, and S.A. Clay. 2019. Propelled abrasive grit applications for weed management in transitional corn grain production. Renew. Agr. Food Syst. 34:33-40, doi: $10.1017 /$ S174217051700031X.

Flavel, T.C. and D.V. Murphy. 2006. Carbon and nitrogen mineralization rates after application of organic amendments to soil. J. Environ. Qual. 35:183-193, doi: 10.2134/jeq2005.0022.

Forcella, F. 2009. Potential of air-propelled abrasives for selective weed control. Weed
Technol. 23:317-320, doi: 10.1614/WT08-099.

Forcella, F. 2012. Air-propelled abrasive grit for postemergence in-row weed control in field corn. Weed Technol. 26:161164, doi: 10.1614/WT-D-11-00051.1.

Forcella, F., T. James, and A. Rahman. 2011. Postemergence weed control through abrasion with an approved organic fertilizer. Renew. Agr. Food Syst. 26:31-37, doi: 10.1017/ S1742170510000438.

Kasirajan, S. and M. Ngouajio. 2012. Polyethylene and biodegradable mulches for agricultural applications: A review. Agron. Sustain. Dev. 32:501-529, doi: 10.1007/s13593-011-0068-3.

Kristoffersen, P., A.M. Rask, and S.U. Larsen. 2008. Non-chemical weed control on traffic islands: A comparison of the efficacy of five weed control techniques. Weed Res. 48:124-130, doi: 10.1111/ j.1365-3180.2007.00612.x.

Kumar, K. and K.M. Goh. 2003. Nitrogen release from crop residues and organic amendments as affected by biochemical composition. Commun. Soil Sci. Plant. 34:2441-2460, doi: 10.1081/CSS120024778 .

Liebman, M. and A.S. Davis. 2000. Integration of soil, crop and weed management in low external-input farming systems. Weed Res. 40:27-47, doi: 10.1046/j.1365-3180.2000.00164.x.

Liebman, M., E.R. Gallandt, and L.E. Jackson. 1997. Many little hammers: Ecological management of crop-weed interactions. Ecol. Agr. 1:291-343.

Little, N.G., C.L. Mohler, Q.M. Ketterings, and A. DiTommaso. 2015. Effects of organic nutrient amendments on weed and crop growth. Weed Sci. 63:710-722, doi: 10.1614/WS-D-14-00151.1.

Mathiassen, S.K., T. Bak, S. Christensen, and P. Kudsk. 2006. The effect of laser treatment as a weed control method. Biosyst. Eng. 95:497-505, doi: 10.1016/ j.biosystemseng.2006.08.010.

Melander, B., I.A. Rasmussen, and P. Barberi. 2005. Integrating physical and cultural methods of weed control examples from European research. Weed Sci. 53:369-381, doi: 10.1614/WS-04136R.

Mikkelsen, R. and T.K. Hartz. 2008. Nitrogen sources for organic crop production. Better Crops Plant Food 92:16-19.

Noll, L.C., A.M. Leach, V. Seufert, J.N. Galloway, B. Atwell, J.W. Erisman, and J. Shade. 2020. The nitrogen footprint of organic food in the United States. Environ. 
Res. Lett. 15:045004, doi: 10.1088/17489326/ab7029.

Nyiraneza, J., A. N'Dayegamiye, M.H. Chantigny, and M.R. Laverdiere. 2009. Variations in corn yield and nitrogen uptake in relation to soil attributes and nitrogen availability indices. Soil Sci. Soc. Amer. J. 73:317-327, doi: 10.2136/ sssaj2007.0374.

Sahin, H. and M. Yalınkllic. 2017. Using electric current as a weed control method. Eur. J. Eng. Res. Sci. 2:59-64, doi: 10.24018/ ejers.2017.2.6.379.
Stadler, C., S. Von Tucher, U. Schmidhalter, R. Gutser, and H. Heuwinkel. 2006. Nitrogen release from plant-derived and industrially processed organic fertilizers used in organic horticulture. J. Plant Nutr. Soil Sci. 169:549-556, doi: 10.1002/jpln.200520579.

Wang, G., M. Ngouajio, and D.D. Warncke. 2008. Nutrient cycling, weed suppression, and onion yield following brassica and sorghum sudangrass cover crops. HortTechnology 18:68-74, doi: 10.21273/HORTTECH.18.1.68.

Wortman, S.E. 2014. Integrating weed and vegetable crop management with multifunctional air-propelled abrasive grits. Weed Technol. 28:243-252, doi: 10.1614/WT-D-13-00105.1.
Wortman, S.E. 2015. Air-propelled abrasive grits reduce weed abundance and increase yields in organic vegetable production. Crop Prot. 77:157-162, doi: 10.1016/j.cropro.2015.08.001.

Wortman, S.E., A.S. Davis, B.J. Schutte, and J.L. Lindquist. 2011. Integrating management of soil nitrogen and weeds. Weed Sci. 59:162-170, doi: 10.1614/ WS-D-10-00089.1.

Zhang, Y., E.S. Staab, D.C. Slaughter, D.K. Giles, and D. Downey. 2012. Automated weed control in organic row crops using hyperspectral species identification and thermal micro-dosing. Crop Prot. 41:96-105, doi: 10.1016/j.cropro. 2012.05.007. 